\title{
Instrument for nursing consultation to pregnant women with diabetes mellitus
}

\author{
Instrumento para consulta de enfermagem a gestantes com diabetes mellitus
}

Thaynara Ferreira Filgueiras ${ }^{1}$, Renan Alves Silva² ${ }^{2}$ Cláudia Jeane Lopes Pimenta ${ }^{1}$, Thiago Ferreira Filgueiras ${ }^{3}$, Simone Helena dos Santos Oliveira ${ }^{1}$, Regia Christina Moura Barbosa Castro ${ }^{2}$

Objective: to construct and validate an instrument to assist the nursing consultation of pregnant women with diabetes mellitus. Methods: methodological study involving the construction of an instrument and evaluation by expert judges in the area who delivered opinions on the objectives, structure, presentation, relevance and content of the instrument of each item. Results: the instrument obtained a satisfactory evaluation in the evaluated criteria, obtaining an index of validity of general content above $85.0 \%$ and index of content validity above $80.0 \%$ in most of the items. Five items were modified according to the recommendations provided by the judges. Conclusion: the content of the instrument was considered valid to guide the nursing consultation, favoring the promotion of quality of life, adoption of healthy life habits and self-care practices, and provides glimpses of emotional, psychological and social aspects that may influence the endocrine modifications during gestation.

Descriptors: Nursing; Validation Studies; Women's Health; Diabetes Mellitus; Nursing Processes.

Objetivo: construir e validar instrumento para auxiliar na consulta de enfermagem às gestantes com diabetes mellitus. Métodos: estudo metodológico, envolvendo a construção de instrumento e avaliação deste por juízes expertise na área, os quais emitiram pareceres acerca dos objetivos, da estrutura, apresentação, relevância e do conteúdo do instrumento de cada item. Resultados: o instrumento obteve avaliação satisfatória em relação aos critérios avaliados, obtendo índice de validade de conteúdo geral superior a 85,0\% e índice de validade de conteúdo superior a $80,0 \%$ na maior parte dos itens. Conforme recomendações dos juízes, cinco itens foram modificados. Conclusão: o conteúdo do instrumento foi considerado válido para orientar na consulta de enfermagem, favorecendo a promoção da qualidade de vida, adoção de hábitos de vida saudáveis e realização de práticas de autocuidado, e vislumbrar aspectos emocionais, psicológicos e sociais que podem influenciar as modificações endócrinas na gestação.

Descritores: Enfermagem; Estudos de Validação; Saúde da Mulher; Diabetes Mellitus; Processos de Enfermagem.

\footnotetext{
${ }^{1}$ Universidade Federal da Paraíba. João Pessoa, PB, Brazil.

${ }^{2}$ Universidade Federal do Ceará. Fortaleza, CE, Brazil.

${ }^{3}$ Universidade Regional do Cariri. Iguatu, CE, Brazil.

Corresponding author: Thaynara Ferreira Filgueiras

Rua Bancário Manoel Geraldo da Silva, 50, apto. 201, Bancários, CEP: 58050300. João Pessoa, PB, Brazil. E-mail: thaynara_filgueiras@ hotmail.com
} 


\section{Introduction}

Diabetes mellitus (DM) is a metabolic disease characterized by hyperglycemia, resulting from defects in insulin excretion and/or action. It can be divided into gestational diabetes mellitus, diagnosed during pregnancy, and pre-gestational diabetes, which consists of diabetes prior to pregnancy: types I, II or others $^{(1)}$.

Gestational diabetes mellitus is classified as carbohydrate intolerance of different degrees of intensity, diagnosed for the first time during the course of gestation, and which may or may not continue after childbirth ${ }^{(1)}$. Type I DM is manifested by total or partial destruction of beta cells, leading to insulin deficiency, divided into $1 \mathrm{~A}$ and $1 \mathrm{~B}$, which are autoimmune and idiopathic cells, respectively ${ }^{(2)}$. In turn, type II DM is the most prevalent (90.0 to $95.0 \%$ ) and occurs at any age, with greater prevalence after 40 years, is characterized by dysfunction in the action and secretion of insulin ${ }^{(3)}$.

DM is a serious health problem due to its prevalence, incidence and early mortality, as well as the generation of costs and expenses involved in the control and treatment of complications. The diagnosis of gestational diabetes implies a high risk for mothers and unborn babies, because perinatal morbidity is increased in these cases when compared to the general population of pregnant women ${ }^{(4)}$. In addition, DM represents one of the main causes of maternal morbidity and mortality in the world; around $1.0 \%$ of pregnancies are correlated with maternal and fetal complications, according to a study carried out in several countries $^{(5)}$.

Diabetes mellitus increases the rate of fetal malformations and alters the growth of the unborn child. The incidence of congenital malformations varies from 5.0 to $10.0 \%$, two to three-fold higher than that observed in the general population, and also accounting for about $40.0 \%$ of perinatal deaths ${ }^{(6)}$. Although there is a notable scientific interest in establishing the precise triggering etiologic factors of this clinical condition, few researchers have quantified the risks of major neonatal complications in pregnant women diagnosed with this disease ${ }^{(7)}$.

It has been demonstrated that the majority of pregnant women present inadequate knowledge about the risks that DM causes to health and are not able to recognize the appearance of complications. Furthermore, the participants were unaware of the harm that this disease could cause to the newborn. Thus, there is a need for maternal counseling, especially regarding the adoption of healthy life habits, aiming at prevention or control of gestational diabetes mellitus $^{(7)}$.

In this sense, it is important to evaluate the level of knowledge of pregnant women about this disease in order to resolve doubts and provide clarification on the control and prevention of problems. Therefore, the role of nurses in outpatient services and primary health care units is extremely relevant.

These professionals have an important influence on pregnant women, through nursing consultations, to encourage their engagement in self-care and in solving basic human needs, in order to provide a better level of health. The development of the nursing consultation requires nurses to gain skills and knowledge; moreover, studies seeking solutions to the detected problems are also needed ${ }^{(8)}$.

It is of utmost importance, therefore, that nurses be able to evaluate clinical conditions in a systematized, continuous and dynamic way, through validated instruments, supported by scientific evidence, to strategically direct the results they seek to achieve, guaranteeing self-care and minimizing or solving future problems that may compromise the lives of mothers and fetuses or newborns ${ }^{(9)}$.

In view of the presented scenario, it was verified that the form used by nurses in nursing consultations was organized according to the proposal of the medical record, whose focus was centered on the disease, not allowing a comprehensive approach to the individual, family and/or community or not allowing the identification of nursing phenomena ${ }^{(10)}$. 
In light of the above, this study aimed to build and validate an instrument to assist the nursing consultation of pregnant women who present diabetes mellitus.

\section{Methods}

Methodological study of a descriptive type, with a quantitative approach, for validation of an instructional instrument content built to be used during nursing consultations to women with diabetes mellitus. The study had two stages: creation of the instrument and face and content validation.

In the first stage, a literature search about DM was carried out, including causal factors or triggers, signs and symptoms, treatment, and life habits. The literature review covered articles in Portuguese and English. To search for articles, the following databases were selected: Latin American and Caribbean Literature in Health Sciences (LILACS); Medical Literature Analysis and Retrieval System Online (MEDLINE); Cumulative Index to Nursing and Allied Health Literature (CINALH); and Web of Science, using the descriptors "Saúde da Mulher" AND "Diabetes Mellitus" AND "Processo de Enfermagem" and their respective translations in the English and Spanish, respectively: "Women's Health" AND “Diabetes Mellitus" AND "Nursing Process", "Women's Health" AND “Diabetes Mellitus" AND "Nursing Process".

The inclusion criteria were: articles published in Portuguese, English and Spanish, with full content, available free of charge, and that approached nursing consultations in prenatal follow-up of pregnant women for the control of diabetes mellitus. Based on the review carried out and the clinical experience of the researchers, an instructional instrument was created as a structured observation script, of the checklist type, composed of 38 items divided into two blocks (general and obstetric data, and information about diabetes mellitus and insulin therapy), considered important in the evaluation of the control of diabetes mellitus in pregnant women.
The general data included the variables: age, origin, marital status, schooling, family income, and occupation. The obstetric data included: gestational age, gestations, parity, abortions, and previous history of complications in previous pregnancies. The data about diabetes mellitus included: type, family history, previous history, glycemic control, adherence to the recommended diet, fasting glycemia in the nursing consultation, number of daily meals, and realization of physical activity. The data about insulin therapy included: guidelines, type of insulin, alternation of application sites, periocity of application, insulin storage, reuse and disposal of syringes, and signs of hypoglycemia and hyperglycemia.

The second stage consisted in the validation of the instrument by judges with nursing training and expertise in the subject. For the selection of judges, the following inclusion criteria were established: qualification (specialists, masters, and doctors), work in the area for at least one year, experience in the subject under discussion in prenatal care services, therapeutic counseling in diabetes, and production and dissemination of studies in this area. Only judges whose profile had at least two of the criteria ${ }^{(11)}$ were included in the evaluation.

The recruitment of judges was made by an initial contact with the coordinator of the Nursing Department of the Federal University of Ceará. Judges were sought in this study center because of the multiplicity of study and research groups directed to obstetric nursing care, prenatal care, pregnancy complications, and sexual and reproductive health. Fifteen nurses who worked with care provision and teaching were identified. An invitation letter was sent to them inviting them to participate in the research, by electronic mail, containing the Informed Consent Form and the Face and Content Validation Instrument of the Observation Script. The e-mail sent to potential judges also provided a brief explanation of the objectives of the study, with an initial deadline of fifteen days to thirty days to return the instrument. If the search instrument was not returned, the deadline would be 
extended for eight further days. Data collection took place between January and February 2017. After the deadline, seven of the fifteen invited professors expressed willingness to participate in the study and only six judges returned the instrument fully evaluated, which composed the sample. This study followed the recommendations of other studies related to the construction and content validation of instruments and scales ${ }^{(12)}$.

Based on the review, 38 items were prepared to be evaluated, considering the following criteria: objectivity, structure, presentation, relevance and content of the instrument. Each item, and the instrument in general, were evaluated using a Likert-type scale with the following response options: inadequate, little adequate, very adequate, and totally adequate. The instrument also had spaces for suggestions and/or comments, so that items could be improved.

The data obtained through the instrument were compiled in the Statistical Package for the Social Sciences, version 22.0. After coding and tabulation, they were analyzed through descriptive statistics.

Categories which scored 3 in the Likert scale, which obtained a favorable approval in a consensus of $75.0 \%$, were considered for the statistical treatment; this agreement index was based on other validation studies $^{(10)}$. In order to calculate the Index of Validity of the General Content, the items classified as very adequate and totally adequate were summed and divided by the total value. The instrument was rewritten according to the suggestions given by the judges ${ }^{(13)}$.

The study took into account the ethical and legal aspects established by Resolution 466/2012 of the National Health Council, and the project was approved by the Research Ethics Committee of the School of Public Health of Ceará, according to protocol no 1.813.420.

\section{Results}

In the first phase, 74 publications were found. However, only 28 studies contributed to the elaboration of the instrument, because the others did not meet all the search criteria. In the second phase, six nurses, experts in the area, evaluated the instrument and analyzed the adequacy of the proposed items.

Initially, a brief characterization of the specialized judges was made. Three $(50.0 \%)$ presented the academic master's degree, two (33.3\%) had PhD, and one (16.7\%) had specialization, thus highlighting good academic training. The time elapsed after graduation varied between 5 and 27 years, with a mean of 12.83 years. The time of experience working in the area ranged from 2 to 27 years, with a mean of 11.17 years. The judges participated in research groups/projects in the area of Maternal Health, had papers published on the theme in the last three years, and four (66.7\%) had presented their thesis/dissertation/monograph in the area of Maternal Health.

In the item "The instrument is appropriate for Nursing Consultation to pregnant women with diabetes in a specialized outpatient clinic", only one of the judges evaluated the item as little adequate. In this sense, it was reported that the instrument had limitations to verify the level of knowledge of pregnant women about the control of the disease. The suggestions were followed and the content of the instrument was expanded to evaluate glycemic control.

Regarding the "spacing" of the text, three $(50.0 \%)$ judges suggested adjustments, which was analyzed and accepted by the authors. Among the six items referring to the General Data of the research, five were considered totally adequate and only one was characterized as little adequate. It is noteworthy that some suggestions were given by the experts for modification or adjustment of the content or structuring of this section evaluated in the items: marital status and origin.

In relation to the item Origin, four judges $(66.7 \%)$ said that the variable was totally adequate, while others suggested adding "Other municipalities" because there are pregnant women living in other cities besides the state capital. In the item Marital status, three (50.0\%) suggested improvement or reformulation, adding to the item the term Divorced.

In the item referring to "Adheres to the recom- 
mended diet", one of the judges suggested adding questions about the presence of difficulties to follow the diet and dietary preferences and habits. In the component "Received guidelines for insulin therapy", one of the judges suggested to add "Did you receive instructions regarding insulin administration, and which professional category provided this information?".

Table 1 - Evaluation by judges of the items of the instrument for nursing consultation to pregnant women with diabetes mellitus

\begin{tabular}{|c|c|c|c|c|c|}
\hline \multirow{3}{*}{ Subdivisions and items of the instrument } & \multicolumn{5}{|c|}{ Opinions of the judges } \\
\hline & Inadequate & $\begin{array}{c}\text { Little } \\
\text { adequate }\end{array}$ & $\begin{array}{c}\text { Very } \\
\text { adequate }\end{array}$ & $\begin{array}{c}\text { Totally } \\
\text { adequate }\end{array}$ & \multirow[t]{2}{*}{ CVI* } \\
\hline & n(\%) & $n(\%)$ & n(\%) & n(\%) & \\
\hline \multicolumn{6}{|l|}{ General data } \\
\hline Age & - & - & - & $6(100.0)$ & 1.00 \\
\hline Origin & - & - & $2(20.0)$ & $4(80.0)$ & 0.80 \\
\hline Marital status & - & $1(10.0)$ & $1(10.0)$ & $4(80.0)$ & 0.80 \\
\hline Schooling & - & - & - & $6(100.0)$ & 1.00 \\
\hline Family income & - & - & - & $6(100.0)$ & 1.00 \\
\hline Occupation & - & - & $2(20.0)$ & $4(80.0)$ & 0.80 \\
\hline \multicolumn{6}{|l|}{ Obstetric data } \\
\hline Gestational age (at diagnosis) & - & - & - & $6(100.0)$ & 1.00 \\
\hline Current gestational age & - & - & - & $6(100.0)$ & 1.00 \\
\hline Gestations; Parity; Abortions (three items) & - & - & - & $6(100.0)$ & 1.00 \\
\hline Complications in previous gestation & - & - & & $6(100.0)$ & 1.00 \\
\hline Data about diabetes & & & - & & \\
\hline Type of diabetes & - & - & - & $6(100.0)$ & 1.00 \\
\hline Family history of diabetes mellitus & - & - & - & $6(100.0)$ & 1.00 \\
\hline Glycemic control & - & - & - & $6(100.0)$ & 1.00 \\
\hline Frequency of glycemic control & - & - & - & $6(100.0)$ & 1.00 \\
\hline Fasting glycemia at the nursing consultation & - & - & - & $6(100.0)$ & 1.00 \\
\hline Adherence to recommended diet & - & - & - & $6(100.0)$ & 1.00 \\
\hline Number of daily meals & - & - & - & $6(100.0)$ & 1.00 \\
\hline Practice of physical activity & - & - & & $6(100.0)$ & 1.00 \\
\hline Data about Insulin Therapy & & & - & & \\
\hline Received guidelines on insulin therapy & - & - & - & $6(100.0)$ & 1.00 \\
\hline Who provided information & - & - & - & $6(100.0)$ & 1.00 \\
\hline The guidelines were satisfactory & - & - & - & $6(100.0)$ & 1.00 \\
\hline Type of insulin used & - & - & - & $6(100.0)$ & 1.00 \\
\hline What is the current insulin dose used & - & - & - & $6(100.0)$ & 1.00 \\
\hline Which application sites are used & - & - & - & $6(100.0)$ & 1.00 \\
\hline Alternates application sites & - & - & - & $6(100.0)$ & 1.00 \\
\hline Frequency of rotation of application sites & - & - & - & $6(100.0)$ & 1.00 \\
\hline Insulin storage & - & - & - & $6(100.0)$ & 1.00 \\
\hline How many times the syringe is reused & - & - & - & $6(100.0)$ & 1.00 \\
\hline How the used syringes are disposed & - & - & - & $6(100.0)$ & 1.00 \\
\hline Covers & - & - & - & $6(100.0)$ & 1.00 \\
\hline Makes a skin foldor application & - & - & - & $6(100.0)$ & 1.00 \\
\hline Feels well with the prescribed dose & - & - & - & $6(100.0)$ & 1.00 \\
\hline Is able to identify signs of hyperglycemia & - & - & - & $6(100.0)$ & 1.00 \\
\hline Knows the care measures in case of hypoglycaemia & - & - & - & $6(100.0)$ & 1.00 \\
\hline Knows the care measures in case of hyperglycemia & - & - & - & $6(100.0)$ & 1.00 \\
\hline General Content Validity Index & & & & & 0.85 \\
\hline
\end{tabular}




\section{Discussion}

Some limitations of this study were the selection of publications that were not accessible free of charge and those that were not available in full length in the databases, as well as the small number of specialists who accepted to participate in the evaluation. However, a summary search of studies produced in four internationally recognized databases was carried out. It was observed that the judges were professionally mature, and represented well the collective wisdom $^{(11)}$, associated with wide experience and development of capacity of social critique and professional self-criticism, attested by the technical-scientific productions. As for the degree and the time elapsed after graduation, important data that confirm the expertise of the judges in the subject, there was predominance of masters and some participants had PhD.

The elaboration of an instrument to guide nursing consultations to pregnant women with diabetes mellitus represents relevant technology for health education and provides guidance for professionals. It allows the optimization of communication between nurses and pregnant women, aims to promote quality of life, adoption of healthy life habits and self-care practices, and aslo addresses emotional, psychological and social aspects that may influence the gestational phase.

Among the participants, the female gender prevailed. This data is in line with other validation studies of instruments in the Nursing area. This characteristic is associated to the fact that the workforce in this profession is composed mostly by women, although the number of males has increased ${ }^{(9)}$.

Given the bureaucratic context experienced in the Nursing area, there is a challenge of inserting the use of the instrument appropriately, and filling it correctly, because studies have reported difficulties of implementation and adherence by professionals to use tools such as checklists in work routines ${ }^{(14)}$. However, the inclusion of the instrument to help in nursing consultations can be considered beneficial in view of the need for more effective actions, trained professionals, and effective technologies ${ }^{(15)}$.

In light of the suggestions put forward by the judges, a positive contribution was made to the items of the instrument, making it evident that, in addition to paying attention to the selected content, they offered criticisms that allowed the adjustment of little appropriate items, such as adding the option of "Divorced" in the item Marital status, the option "Other municipalities" in the item "Origin", and other changes that were accepted.

The judges also mentioned the need to add specifications related to nutritional practices such as preferences and eating habits and the presence of difficulties to adhere to the recommended diet. Nutritional guidance during prenatal care should take into account the prevention, diagnosis and treatment of inadequate weight gain, as well as the intercurrences that may occur during pregnancy, such as hypertensive syndromes and gestational diabetes mellitus ${ }^{(16)}$.

A review study on nutritional characteristics during pregnancy showed that women presented inadequate diet to meet their energy needs, with a low consumption of meat, greenery, fruits and vegetables, which is associated, in many cases, with socioeconomic and routine difficulties and family behavior ${ }^{(17)}$.

In view of this situation, health professionals play a relevant role in promoting the health of these women. It is necessary to consider the influence of popular knowledge and the family context to adopt healthy eating practices, which requires the establishment of strategies that allow the approximation between knowledge and the culture of pregnant women and their families ${ }^{(18)}$.

Regarding the marital situation, it was suggested that the option divorced was added. In a case-control study conducted with mothers of live births in Londrina, Brazil, it was observed that the variable "mother who resided with the partner for a maximum of two years" - considered an unstable union - was 
understood as a possible factor of mother's insecurity and presented a significant association with the newborn, which may have a direct influence on the gestational period ${ }^{(19)}$.

The empowerment of pregnant women with the diagnosis of diabetes mellitus is necessary in view of the high incidence and prevalence of the disease. However, a study conducted in Fortaleza, Brazil, on which professionals provided information about the disease during prenatal care found that $58.8 \%$ of the respondents answered that they had received no information about the disease. Only $17.6 \%$ stated that they had received the information from nurses; $17.6 \%$ from physician; and $6.0 \%$ from pharmacy profession$\operatorname{als}^{(6)}$.

Another study carried out in Salvador, Brazil, showed that although the pregnant women had some knowledge about the disease and its complications, this information was fragmented and incomplete. There were negative feelings related to this clinical condition, especially in relation to the potential risks for the baby ${ }^{(20)}$. It is therefore imperative that the professionals of the health team investigate the knowledge of these women, highlighting, among other aspects, the presence of fears and longings, and seeking to understand the difficulties faced daily.

The health professionals represent important actors for pregnant women with gestational diabetes mellitus and their families. It is necessary that these professionals act ethically and based on the principles of universality, comprehensiveness and equity, in order to provide quality care that promote security, well-being and co-responsibility of those involved.

The analysis of the judges allowed to make modifications in the instrument, promoting content validity. However, further studies are fundamental to evaluate the psychometric properties of the instrument, such as internal consistency and reliability. It is hoped that the instrument become a tool for nursing consultation in the specialized outpatient service, due to the scarcity of validated materials that allow documentation of nursing care to this public.

\section{Conclusion}

The content of the instrument was considered valid to guide nursing consultations to pregnant women with diabetes mellitus, favoring the promotion of quality of life, adoption of healthy life habits, and self-care practices, as well as provides a glimpse of emotional, psychological and social aspects that may influence endocrine changes in the gestational phase.

\section{Acknowledgements}

To the Escola de Saúde Pública do Ceará, for granting a scholarship to the Obstetric Nursing Home.

\section{Collaborations}

Filgueiras TF, Silva RA and Castro RCMB contributed to the conception and design, data analysis and interpretation, article writing and critical review of the intellectual content. Pimenta CJL, Filgueiras TF and Oliveira SHS collaborated with the writing and critical review of the intellectual content. All authors assisted in the final approval of the version to be published.

\section{References}

1. American Diabetes Association. Classification and diagnosis of diabetes: Standards of Medical Care in Diabetes - 2018. Diabetes Care. 2018; 41(Supl. 1):13-27. doi: https://doi.org/10.2337/ dc18-S002

2. Orozco LB, Alves SHS. Diferenças do autocuidado entre pacientes com diabetes mellitus tipo $1 \mathrm{e}$ 2. Psic Saúde Doenç. 2017; 18(1):234-47. doi: http://dx.doi.org/10.15309/17psd180119

3. Sociedade Brasileira de Diabetes. Diretrizes da Sociedade Brasileira de Diabetes, 2017-2018 [Internet]. 2017 [citado 2019 jan. 20]. Disponível em: https://www.diabetes.org.br/profissionais/ i mages / 2017 / diretrizes / diretrizessbd-2017-2018.pdf 
4. Costa RC, Campos MOC, Marques LARV, Rodrigues Neto EM, Franco MC, Diógenes ESG. Diabetes gestational assisted: profile and knowledge of pregnant women. Rev Saúde. 2015; 41(1):131-9. doi: http://dx.doi.org/10.5902/2236583413504

5. Hildén $K$, Hanson U, Persson M, Magnuson A, Simmons D, Fadl H. Gestational diabetes and adiposity are independent risk factors for perinatal outcomes: a population based cohort study in Sweden. Diabet Med. 2019; 36(2):151-7. doi: http://dx.doi.org/10.1111/dme.13843

6. Silva AL, Amaral AR, Oliveira DS, Martins L, Silva MR, Silva JC. Neonatal outcomes according to diferente therapies for gestational diabetes mellitus. J Pediatr. 2017; 93(1):87-93. doi: https:// doi.org/10.1016/j.jped.2016.04.004

7. Borges MCV, Souza Júnior JA, Ribeiro LAN, Ribeiro MF, Oliveira PC, Reis RMS, et al. O conhecimento das gestantes sobre o diabetes mellitus gestacional em unidade de pré-natal no sul de Minas Gerais. Arch Health Invest. 2017; 6(8):348-51. doi: http://dx.doi.org/10.21270/archi.v6i8.2089

8. Lucena AF, Magroa CZ, Proençab MCC, Piresa AUB, Moraes VM, Alitia GB. Validation of the nursing interventions and activities for patients on hemodialytic therapy. Rev Gaúcha Enferm. 2017; 38(3):e66789. doi: dx.doi.org/10.1590/19831447.2017.03.66789

9. Rabasová P. Content validation of nursing diagnosis of deficient fluid volume [dehydration] in the context of neonatological nursing. Cent Eur J Nurs Midwifery. 2017; 8(2):622-31. doi: http:// dx.doi.org/10.15452/CEJNM.2017.08.0011

10. Domingos CS, Moura PC, Braga LM, Rodrigues NV, Correia MDL, Carvalho AMP. Construction and validation of the historical contents of nursing guided by Orem reference. Rev Min Enferm. 2015; 19(2):176-18. doi: dx.doi.org/10.5935/14152762.20150033

11. Lopes MVO, Silva VM, Herdman TH. Causation and validation of nursing diagnoses: a middle range theory. Int J Nurs Knowl. 2017; 28(1):53-9. doi: https://doi.org/10.1111/2047-3095.12104

12. Medeiros RKS, Ferreira Júnior MA, Pinto DPSR, Vitor AF, Santos VEP, Barichello E. Modelo de validação de conteúdo de Pasquali nas pesquisas em Enfermagem. Rev Enf Ref. 2015; 4(4):127-35. doi: http://dx.doi.org/10.12707/RIV14009
13. Machado RC, Gironés P, Souza AR, Moreira RSL, Von Jakitsch CB, Branco JNR. Nursing care protocol for patients with a ventricular assist device. Rev Bras Enferm. 2017; 70(2):335-41. doi: http://dx.doi. org/10.1590/0034-7167-2016-0363

14. Vohra RS, Cowley JB, Bhasin N, Barakat HM, Gough MJ. Attitudes towards the surgical safety checklist and factors associated with its use: a global survey of frontline medical professionals. Ann Med Surg. 2015; 4(2):119-23. doi: https://doi. org/10.1016/j.amsu.2015.04.001

15. Melo GAA, Silva RA, Pereira FGF, Caetano JA. Cultural adaptation and reliability of the General Comfort Questionnaire for chronic renal patients in Brazil. Rev Latino-Am Enfermagem. 2017; 25:e2963. doi: http://dx.doi.org/10.1590/15188345.2280.2963

16. Ministério da Saúde (BR). Protocolos da Atenção Básica: saúde das mulheres [Internet]. 2016 [citado 2019 jan. 01]. Disponível em: http://189.28.128.100/dab/docs/portaldab/ publicacoes/protocolo_saude_mulher.pdf

17. Bueno AA, Beserra JAS, Weber ML. Características da alimentação no período gestacional. Life Style J. 2016; 3(2):29-42. doi: https://doi. org/10.19141/2237-3756/lifestyle.v3.n2.p30-43

18. Junges CF, Ressel LB, Monticelli M. Amongst wishes and possibilities: eating habits of pregnant women from an urban community in Southern Brazil. Texto Contexto Enferm. 2014; 23(2):382-90. doi: dx.doi.org/10.1590/0104-07072014000210013

19. Silva AMR, Almeida MF, Matsuo T, Soares DA. Risk factors for preterm births in Londrina, Paraná, Brasil. Cad Saúde Pública. 2015; 25(10):212538. doi: http://dx.doi.org/10.1590/S0102311X2009001000004

20. Mançu TS, Almeida OSC. Knowledge and feelings of diabetic pregnant women about gestational diabetes mellitus and treatment. Rev Enferm UFPE on line [Internet]. 2016 [cited Jan 13, 2019]; 10(3):1474-82. Available from: https:// periodicos.ufpe.br/revistas/revistaenfermagem/ article/view/11089/12538 